\title{
ZALOŻENIA RAMOWE PROGRAMU BUDOWY MUZEUM ARCHIDIECEZJALNEGO W KATOWICACH
}

\section{Założenia ogólno-prawne}

1. Muzeum Archidiecezjalne w Katowicach zgodnie z obowiązującymi założeniami statutowymi jest placówką podległą jurysdykcji Biskupa Katowickiego. Minister Kultury i Sztuki realizuje uprawnienia wynikające z ustawy o ochronie dóbr kultury i o muzeach w uzgodnieniu z miejscowym Ordynariuszem.

a. Ponieważ instytucje funkcjonują tak jak zostały nazwane nie byłoby właściwe stosowanie nazw sugerujących podległość w stosunku do innych placówek muzealnych, takich jak Muzeum Śląskie. Nazwy takie jak Muzeum Sztuki Religijnej, lub „Oddział...”, względnie „Dział...” sugerują albo zawężenie funkcji muzeum, albo zależność od innej placówki.

b. Podległość jurysdykcji właściwego biskupa nie wyklucza szeroko pojętej współpracy Muzeum Archidiecezjalnego z innymi podobnymi placówkami kultury. W dotychczasowej praktyce taka współpraca istnieje i jest konieczna.

c. Funkcjonowanie Muzeum Archidiecezjalnego jako instytucji wskazującej na tożsamość Kościoła Katolickiego, w zespole instytucji dokumentujących kulturę na Górnym Śląsku służyłoby wyodrębnieniu charyzmy Kościoła. Nie może zespół sztuki sakralnej jako pomnik wiary pokoleń, stanowić kolekcję dokumentującą wyłącznie rozwój formy artystycznej, świadectwo zjawisk o charakterze etnograficznym, czy wręcz kostiumologicznych.

d. Właściwa podmiotowość i podległość Muzeum Archidiecezjalnego nie wyklucza nachylenia ekumenicznego tej placówki, co stwarzałoby forum współpracy z innymi kościołami, a także z judaizmem.

e. Dla bogatszego zobrazowania duchowości i kultury religijnej Górnego Śląska, a także podjęcia badań można rozważyć warunki współpracy trzech diecezji wchodzących w skład Metropolii, służącej powstaniu instytucji o znacznym oddziaływaniu i dużym prestiżu. W perspektywie mającego 
powstać kompleksu wystawienniczego na terenie dawnej „Kopalni Katowice", używa się w odniesieniu do planowanych inwestycji takich terminów jak Katowicki lub Górnośląski „Akropol.”

2. $\mathrm{Z}$ zasady podległości placówki muzealnej biskupowi miejsca wynika:

a. Realizacja celów statutowych muzeum w odniesieniu do Archidiecezji, lub Metropolii, stanowiących podmiot działalności Muzeum.

b. Wskazanie i zabezpieczenie przez Archidiecezję źródeł utrzymania muzeum umożliwiających mu realizację celów statutowych zgodnych z wymogami współczesnego muzealnictwa.

3. Budowa budynku Muzeum Archidiecezjalnego w Katowicach jest przejawem troski katolickiego społeczeństwa na Górnym Śląsku o zachowanie pamięci, stanowiącej o tradycji wiary i tożsamości Kościoła na Górnym Śląsku.

a. Idea budowy Muzeum powinna być właściwie przedstawiona społeczeństwu katolickiemu na Górnym Śląsku. Odnośne dyrektywy Stolicy Apostolskiej na temat ochrony Dóbr Kulturalnych Kościoła ukazują istotny charakter posługi muzeów kościelnych.

b. Budowę Muzeum Archidiecezjalnego mogłaby wspierać ustanowiona przez biskupa Fundacja Budowy Muzeum. Budowa Muzeum, którego działalność rzutuje w przyszłość winna być przedmiotem konsultacji. Po ukończeniu budowy Muzeum niektórzy członkowie Fundacji mogliby zostać włączeni w skład Rady Muzeum.

\section{Programowanie przestrzeni muzealnej w świetle zadań statutowych tej instytucji}

1. Z celów statutowych muzeum określających zadania tej placówki wynika zakres prac projektowych kształtujących przestrzeń nowego Muzeum. Muzeum Diecezjalne jak każde muzeum inwentaryzuje, gromadzi, przechowuje, prowadzi działalność badawczą, oświatową, wydawniczą, udostępnia i konserwuje własne zbiory. Biorąc pod uwagę przyjętą praktykę muzealną w pracach projektowych należy uwzględnić:

a. Ukształtowanie takiej przestrzeni magazynowej, która zabezpieczałaby działalność poszczególnych działów muzealnych.

- dział sztuki dawnej zabezpiecza malarstwo, grafikę rzeźbę, rzemiosło artystyczne, tkaninę artystyczną. Poszczególne rodzaje obiektów wymagają osobnych sposób przechowywania i odrębnych przestrzeni magazynowych, co rzutuje na dalsze wyposażenia magazynów w profesjonalny sprzęt do magazynowania dzieł sztuki.

- dział sztuki współczesnej gromadzący prace na płótnie i papierze, rzeźbę, instalacje artystyczne.

- dział historyczny gromadzący pamiątki diecezjalne i regionalne dotyczące wydarzeń, instytucji, osób. 
— dział misjologiczny zabezpieczający dokumentację misyjnej działalności śląskich kapłanów.

- gabinet numizmatów i medali zabezpiecza przedmioty o zróżnicowanym gabarycie od dużych form po małe, łatwe do zagubienia medaliki. Sposób przechowywania tych przedmiotów określa praktyka muzealna.

- magazyn starodruków i archiwum akt własnych. Nasze Muzeum przechowuje druki oficyn śląskich i posiada już bogaty zasób archiwaliów dokumentujących własną działalność.

- magazyn księgozbioru podręcznego w zakresie sztuki i muzealnictwa. Ukształtowanie powierzchni magazynowej powinno poza specyfiką magazynowania poszczególnych obiektów uwzględniać:

- możliwość prowadzenia pracy badawczej na terenie magazynu

- zabezpieczenie magazynu pod względem bezpieczeństwa zbiorów i uwarunkowań konserwatorskich (klimatyzacja, światło).

b. Ukształtowanie przestrzeni ekspozycyjnej odpowiadającej charakterystyce poszczególnych działów i specyfice diecezji $\mathrm{W}$ odniesieniu do naszych zbiorów stałą ekspozycję powinny mieć:

- sztuka gotycka,

— nowożytna sztuka sakralna,

- numizmaty,

- galeria malarstwa historycznego,

- galeria sztuki współczesnej obrazującej dokonania i poszukiwania artystyczne w zakresie nowoczesnej sztuki sakralnej,

- galeria pamiątek historycznych. Muzeum posiada zbiory pamiątek osób prywatnych (m.in. po Marii Korfanty Ullmann), których nie eksponuje $\mathrm{z}$ braku miejsca,

- wystawa obrazująca tradycję budownictwa sakralnego i wyposażenia kościołów od poł. XIX w. po współczesność,

- wystawa obrazująca religijność ludową, praktyki pobożne i duszpasterskie na Górnym Śląsku,

- wystawa dokumentująca działalność biskupów i duchowieństwa Diecezji i Archidiecezji Katowickiej,

- wystawa obrazująca historię katedry i lokalnych sanktuariów.

Tematyka wystaw stałych jest sprawą otwartą. Przekrój stałych wystaw powinien obrazować historię diecezji, przejawy życia religijnego, działalność osób, stowarzyszeń i ruchów kościelnych. O atrakcyjności wystaw stałych decyduje aranżacja wystawy, zastosowanie środków multimedialnych, właściwe oświetlenie.

c. Przestrzenie dla wystaw zmiennych powinny tak być ukształtowane by stanowiły odrębny trakt poza ciągiem wystaw stałych. Ważna dla traktu wystaw zmiennych są ułatwienia komunikacyjno-magazynowe.

- stałą przestrzeń dla wystaw zmiennych powinna mieć Galeria Sztuki Współczesnej „Fra Angelico” stanowiąca miejsce spotkań środowisk twórczych. Przestrzeń tej galerii powinna być elastyczna i dostosowana 
do organizacji wystaw małych i wielkich, obiektów miniaturowych i wysokich (jak kartony witrażowe). Powinna także uwzględniać możliwość organizacji dwu, a nawet trzech wystaw w jednym czasie w zależności od potrzeb. Elastyczność tej przestrzeni powinna pozwalać na wyłączanie przestrzeni zbędnych, kiedy zajdzie taka potrzeba.

- stałą przestrzeń dla zmiennych wystaw historycznych i wystaw ruchomych przyjmowanych $\mathrm{z}$ innych muzeów należy zsynchronizować z przestrzeniami Galerii Sztuki Współczesnej. Elastyczność w kształtowaniu tych przestrzeni pozwoli na ergonomiczne ich wykorzystanie.

- w trakcie wystaw zmiennych należy uwzględnić przestrzeń magazynową dla przechowywania czasowego wystaw, a także przestrzeń gospodarczo-warsztatową.

d. Pracownię konserwatorską ze względu na konieczność stałego nadzoru nad pokaźnym zasobem sztuki dawnej znajdującej się w inwentarzu muzealnym. Pracownia taka powinna posiadać osobny magazyn, właściwe miejsce pracy konserwatorskiej i wydzielone miejsce dla pracy biurowej kierownika pracowni.

— w zespoleniu z pracownią konserwatorską należy zaprojektować osobna pracownię fotograficzną.

e. Pracownie dla osób zatrudnionych w Muzeum,

- biuro administracji Muzeum i gabinet dyrektora wraz z niewielką salą konferencyjną jako miejscem spotkań z personelem, gośćmi Muzeum, przedstawicielami mediów etc.,

- pracownia inwentaryzatorska z przyległym pomieszczeniem dla osób podejmujących się prac badawczych w Muzeum,

- pracownia dla pracowników merytorycznych, w tym dla działu wydawniczego i oświatowego dla ok. 4 osób,

- pomieszczenie dla personelu pomocniczego.

f. Salę audiowizualną jako miejsce projekcji, koncertów, uroczystych wernisaży i spotkań, konferencji.

2. Muzeum jako przestrzeń publiczna jest miejscem gromadzenia się grup i gremiów, które spotykają się w Muzeum z różnych okazji. Są to grupy zwiedzających, środowisk twórczych, konferencji naukowych, uroczystych wydarzeń muzealnych, uczestników koncertów, spektakli i prelekcji. W związku z tym należy przewidzieć:

a. Funkcjonalnie ukształtowane trakty komunikacyjne łączące poszczególne przestrzenie wystawowe z uwzględnieniem dostępności dla osób niepełnosprawnych i łatwości w transporcie muzealiów przewidzianych na wystawy. Konieczność zainstalowania windy towarowej,

b. Halle poprzedzające ciągi wystawiennicze służące także jako miejsca gromadzenia się grup i gości wernisażowych,

c. Dostępne: recepcja, szatnie i sanitariaty. Pomieszczenia takie znajdują się zwykle w muzeach blisko głównego wejścia lub wyjścia, 
d. Na styku wejścia i wyjścia umieszcza się zwykle księgarnię-kiosk muzealny i kawiarnię.

3. Muzeum z racji przyznawanych jej funkcji zawsze wyróżniała bryła budynku i jej otoczenie.

a. Charakter zewnętrzny budowli powinien wskazywać na jego funkcję jako muzeum sztuki religijnej i pamiątek życia religijnego na Górnym Śląsku.

b. W nurcie przyjętych aktualnie trendów muzealnych wnętrze muzeum i jego otoczenie powinno być nie tylko miejscem zdobycia wiedzy, ale także przestrzenią odpoczynku i refleksji nad wartościami jakie ujawniły się w przeszłości. W przypadku muzeum kościelnego powinno to być także miejsce sprzyjające kontemplacji, modlitwie i ewangelizacji. Interesujące dla przestrzeni takiego muzeum wydaje się myślenie projektowe prof. Marka Budzyńskiego. Podług jego projektu Świątyni Opatrzności Bożej, otoczenie tej świątyni przywoływało klimaty polskiego pejzażu z widocznymi znakami religijnymi tego pejzażu.

- wprowadzenie do przestrzeni muzealnej, względnie zainstalowanie w jej otoczeniu punktu sakralnego stanowiłoby ułatwienie dla duszpasterstwa jakie powinno być prowadzone przy Muzeum w stosunku do środowisk twórczych jak i osób odwiedzających cały „Górnośląski Akropol". Funkcję duszpasterską spełnia kościół drewniany z Nieboczów zainstalowany w przestrzeni muzealnej jaką jest skansen chorzowski.

- miejscem instalacji punktu sakralnego mogłoby być np. patio muzealne. Wyznaczałby on wtedy pewien punkt orientacyjny dla całego założenia architektonicznego i podkreślał to, co pisał o istocie muzealnictwa kościelnego prof. Mennis, hiszpański jezuita: „muzeum kościelne funkcjonując $\mathrm{w}$ oparciu o powszechnie przyjęte praktyki muzealne, jest jednak innym muzeum".

\section{Strategia}

W świetle zamierzeń Urzędu Marszałkowskiego związanych z budową kompleksu nazwanego „Górnośląskim Akropolem”, lub „Kopalnią sztuki” jakie zostały mi przedstawione w Urzędzie Marszałkowskim dn. 17 lutego 2005 r. planowanie budowy budynku Muzeum Archidiecezjalnego przedstawia się następująco:

1. Urząd Marszałkowski akceptuje pomysł prezentacji zbiorów sztuki religijnej w przewidzianym do budowy zespole muzealno-wystawienniczym.

2. Pomysł na przyznanie konkretnego budynku dla Muzeum Archidiecezjalnego, z tych, które istnieją wydaje się najmniej szczęśliwy:

a. budynki te w obecnym stanie wymagają adaptacji dla celów wystawienniczych. 
b. sposób adaptacji istniejących budynków wyniknie z ogólnego planowania przestrzeni wystawienniczych,

c. architektura tych budynków ma spełniać głównie funkcję symboliczną.

3. Działka wyznaczona pod przeszłe pawilony wystawiennicze znajduje się w gestii Urzędu Miasta Katowice. W razie gdyby Archidiecezja zamierzała na tym terenie budować własne Muzeum należy wystąpić o przyznanie na tym terenie parceli. Może to dokonać się w porozumieniu z Muzeum Śląskim, które stało się prawnym użytkownikiem działki.

4. Urząd Marszałkowski poddaje pod rozwagę dwie możliwości prezentacji zbiorów sztuki religijnej w mającym powstać kompleksie wystawienniczym:

a. włączenie kolekcji Muzeum Archidiecezjalnego do kolekcji Muzeum Śląskiego jako odrębny dział sztuki religijnej. W tej sytuacji:

- obowiązywałaby podległość administracyjna i programowa kierownika działu sztuki religijnej dyrektorowi Muzeum Śląskiego,

- Kolekcja Muzeum Archidiecezjalnego zostałaby utrzymana na zasadzie depozytu Kurii Metropolitalnej. Przedstawiciel Kurii Metropolitalnej delegowany przez księdza Arcybiskupa wchodziłby w skład Rady Muzeum Śląskiego,

- utrzymanie działu sztuki religijnej, ewentualnego programu wystaw czasowych i pracującego $\mathrm{w}$ nim personelu wynikałoby z ogólnego budżetu jakim dysponowałoby Muzeum Śląskie,

- istniałaby możliwość wydzielenia osobnego budynku dla działu sztuki religijnej.

b. Budowa budynku na terenach wystawowych jako Muzeum Archidiecezjalnego, posiadającego własną osobowość prawną. W tej sytuacji:

— do rozważenia pozostawałby pełny program budowy własnego Muzeum przedstawiony wyżej w zarysie,

- środki na budowę budynku Muzeum Archidiecezjalnego pochodziłyby w ustawowo przewidzianym procencie ze środków unijnych, o które należałoby wystąpić; w części byłyby to środki własne,

— istnieje możliwość ustawowa występowania o środki na dofinansowanie programów merytorycznych,

- nie istnieje możliwość ustawowa bieżącego utrzymania Muzeum Archidiecezjalnego z budżetu Marszałka Województwa Śląskiego,

- zgodnie z zarządzeniem Ministra Kultury i Sztuki „Muzeum działa na postawie statutu nadanego mu przez podmiot w uzgodnieniu z Ministrem Kultury i Sztuki” oraz „Podmioty tworzące muzea są zobowiązane zapewnić środki utrzymania i rozwoju muzeum oraz bezpieczeństwo zgromadzonym zbiorom”.(Dz. Ustaw, nr 5/20 I 1997, Rdz. 2 art. 5 pkt. 2 i 3 i art.6 pkt. 1.),

- zgodnie z zarządzeniem Ministra Kultury i Sztuki (Dz. Ustaw, nr 5/20 I 1997 Rdz. 3. art. 13) istnieje możliwość wpisania Muzeum do wykazu „Muzeów rejestrowanych”. Podstawą wpisu do rejestru jest uznanie 
znaczenia posiadanych przez Muzeum zbiorów, wykazanie się zespołem kwalifikowanych pracowników i pomieszczeń, oraz zapewnienie muzeum stałego źródła utrzymania. Takie Muzeum korzysta ze szczególnej ochrony i pomocy finansowej państwa.

5. Urząd Marszałkowski zamierzając ogłosić konkurs na zagospodarowanie przestrzeni przeznaczonej pod pawilony wystawiennicze na terenie dawnej Kopalni Katowice wyznacza do końca marca br. termin zgłaszania programów ogólnych przez instytucje zainteresowane budową własnego Muzeum (jak Muzeum Archidiecezjalne), bądź programu działu, który stanowiłby część programu Muzeum Śląskiego.

Katowice, 12 marca 2005 